\title{
Optical CBC Block Encryption Method using Free Space Parallel Processing of XOR Operations
}

\author{
Sang Keun Gil ${ }^{\dagger}$ \\ Department of Electronic Engineering, The University of Suwon, Whasung 440-600, Korea
}

(Received September 3, 2013; Revised manuscript October 10, 2013; Accepted October 10 2013)

\begin{abstract}
In this paper, we propose a modified optical CBC(Cipher Block Chaining) encryption method using optical XOR logic operations. The proposed method is optically implemented by using dual encoding and a free-space interconnected optical logic gate technique in order to process XOR operations in parallel. Also, we suggest a CBC encryption/decryption optical module which can be fabricated with simple optical architecture. The proposed method makes it possible to encrypt and decrypt vast two-dimensional data very quickly due to the fast optical parallel processing property, and provides more security strength than the conventional electronic $\mathrm{CBC}$ algorithm because of the longer security key with the two-dimensional array. Computer simulations show that the proposed method is very effective in $\mathrm{CBC}$ encryption processing and can be applied to even ECB(Electronic Code Book) mode and CFB(Cipher Feedback Block) mode.
\end{abstract}

Keywords: Optical encryption, Optical XOR logic, Cipher block chaining(CBC), Free-space parallel processing OCIS codes: (200.4660) Optical logic; (200.3760) Logic-based optical processing; (200.2610) Free-space digital optics; (070.4560) Data processing by optical means

\section{XOR 연산의 자유 공간 병렬 처리를 이용한 광학적 CBC 블록 암호화 기법 길상근 수원대학교 전자공학과 \\ (우 440-600 경기도 화성시 봉담읍 와우안길 17}

(2013년 9월 3일 받음, 2013년 10월 10일 수정본 받음, 2013년 10월 10일 게재 확정)

본 논문에서는 블록암호화의 CBC(Cipher Block Chaining) 방식을 광학적인 XOR 연산을 이용하여 새로운 변형된 CBC 암호화 및 복호화 시스템을 제안한다. 제안한 방법은 광학적 XOR 연산의 병렬 처리를 위해 이중 인코딩 방법과 자유 공간 연결 광 논리 게이트 방법을 사용한다. 또한 제안된 XOR 연산 기반의 $\mathrm{CBC}$ 암호화 방식의 광학적 구성도를 공학적으로 실제 제작 구현 가능한 광 모듈 형태의 광 암호화/복호화 장치로 제안한다. 제안된 방법은 기존의 $\mathrm{CBC}$ 방식을 광학적으로 구현했기 때문에 기존 의 전자적인 $\mathrm{CBC}$ 방식의 장점과 광학적인 고속성과 병렬 처리의 특성으로 인해 많은 정보를 빠른 속도로 암호화 및 복호화가 가능하다. 또한, 광 병렬 처리의 특성상 데이터가 2 차원으로 배열되어 데이타 크기가 증가된 평문 데이터와 암호키를 사용함으로 써 기존의 전자적 $\mathrm{CBC}$ 방식보다도 한층 더 암호 강도가 강력해진 암호화 시스템을 제공한다. 컴퓨터 시뮬레이션 결과는 제안한 기법이 $\mathrm{CBC}$ 모드의 암호화 및 복호화 과정에 효율적임을 보여준다. 한편 제안된 방식은 $\mathrm{CBC}$ 방식 외에 $\mathrm{ECB}$ (Electronic Code Book) 방식과 CFB(Cipher Feedback Block) 방식에도 적용할 수 있다.

Keywords: 광학적 암호화, 광 $\mathrm{XOR}$ 논리, $\mathrm{CBC}$ 방식 암호화, 자유 공간 병렬처리

OCIS codes: (200.4660) Optical logic; (200.3760) Logic-based optical processing; (200.2610) Free-space digital optics; (070.4560) Data processing by optical means

\section{I. 서 론}

최근에 점차적으로 개인 정보의 불법 유출과 정보의 해킹
등의 문제로 인하여 사생활의 침해뿐만 아니라 막대한 경제 적인 손실을 유발하고 있다. 이러한 이유로 최근에 와서 공 중망에 대한 정보의 보호가 중요해졌고 정보 보안을 강화시

${ }^{\dagger}$ E-mail: skgil@suwon.ac.kr

Color versions of one or more of the figures in this paper are available online. 
키는 방법의 일환으로 DES(Data Encryption Standard), AES (Advanced Encryption Standard)와 같은 전자적 디지털 암호 화 방식을 만들어 사용해 오고 있다 ${ }^{[1]}$. 통상적으로 암호화란 암호화하고자 하는 평문(plain text)을 사전에 약속한 암호화 키(security key)를 이용하여 암호문(cipher text)로 변환하는 과정을 말하며, 이렇게 전송된 암호문을 똑같은 암호화 키로 복호화하는 과정이다. 하지만 암호화 강도 면에서 기존의 디 지털 암호화 기술은 컴퓨터 장비들의 향상으로 인해 점점 더 암호 해석 공격으로부터 그 취약점이 노출되고 있으며 다가 오는 미래에서는 정보들을 보호할 수가 없게 되어 버릴 것이 다. 또한 머지않아 정보의 용량뿐만 아니라 처리 속도 면에 서도 그 한계를 드러낼 것이다 ${ }^{[2]}$. 이와 같은 문제를 해결하기 위해 1990년대 초부터 여러 가지 방식의 광학적 기술을 적 용한 암호화 기법이 지속적으로 연구되어 왔다. 대표적인 광 암호화 기법으로는 Javidi그룹이 수행한 이중 무작위 위상 인코딩(double random phase encoding) 기법을 이용한 방법 ${ }^{5,}$ ${ }^{6]}$ 이 있으며, 이 밖에도 결합 변환 상관기(JTC)를 이용한 방 법 $^{[7,8]}$, 위상 대비를 이용한 방법 ${ }^{[9]}$, 분수차 푸리에 변환을 이 용한 방법 ${ }^{[10]}$, 디지털 위상 천이 간섭계를 이용한 방법 ${ }^{[11-13]}$ 등 그 외에 다양한 암호화 기법들 ${ }^{[14-20]}$ 이 연구되어 발표되었 다. 하지만 이러한 방법들 중 대부분은 주파수 영역의 복소 함수를 다룸으로써 광학 시스템의 광축 정렬 문제나 외부 교 란에 의한 민감한 단점을 지니고 있다. 또한 현재 연구되어 오는 대부분의 광학적 암호화 기법은 홀로그래피 특성을 이 용한 복소 함수 형태의 암호문을 생성하기 때문에 디지털 통 신망을 이용해 암호문을 전달시키기 위해서는 디지털 데이 터 변환 과정과 그 처리 시간이 요구된다. 이를 해결하기 위 해서 디지털 처리 방식인 XOR 연산을 이용한 광 암호화 기 법이 제안되었으며, 이 중에서 $\mathrm{LCD}$ (Liquid Crystal Device) 에 의한 빛의 편광을 이용하여 광학적으로 XOR 연산을 수 행함으로써 gray-level 영상을 암호화 하는 기법 ${ }^{[16]}$ 이 제안되 었다. 이 방법은 gray-level영상을 이진(binary)수의 bit 수만 큼 나눈 이진 영상을 XOR연산 암호화하는 방법으로 암호화 된 8개의 이진 영상들은 각각 암호화 키에 의해 얻어진다. 하지만 이 방법은 각각의 암호화된 이진 영상을 통해 암호화 키가 추적될 수 있는 단점이 있다. 또 다른 방법으로 두 이 진 위상 영상간의 광학적 간섭을 이용한 XOR 암호화 기법 ${ }^{[18]}$ 이 제안되었는데 이 방법은 이진 위상간의 간섭을 이용하 므로 gray-level 영상의 암호화에는 한계점을 가지고 있다. 이러한 문제를 해결하기 위해 gray-level 원 영상에 대해 디 지털적인 phase-encoded XOR 연산 기반의 암호화 방법 ${ }^{[19]}$ 이 제안되었는데, 이 방법은 암호화 영상을 만들고 이를 위상 부호화하여 광학적 복호화 시스템으로 원 영상을 복원하는 방법이다. 하지만 이 방법도 두 영상간의 화소 정합 정렬 문 제와 두 영상간의 정확한 위상 간섭을 위한 정밀한 광학 정 렬이 요구된다. 특징적으로 광학적 시스템은 2차원 데이터를 병렬 처리할 수 있는 장점을 가지고 있다. 이것은 대용량의 데이터를 매우 빠른 속도로 처리할 수 있게 한다. 일반적으 로 기존의 전자적 암호화 방식들은 이진 데이터를 사용한다.
따라서 기존에 사용하였던 디지털적인 알고리즘을 이용하여 광학적 암호화 기법을 구현하면 전자적 디지털 보안 기법에 비하여 정보의 크기, 처리 속도가 월등한 능력을 가지는 장 점을 가지고 있기 때문에 현대에서 디지털 보안 기법의 대안 으로서 매우 유용하게 사용될 수 있다.

본 논문에서는 원 gray-level 영상을 이진화하여 암호화할 입력 데이터로 변환한 다음, 이중 인코딩(dual encoding) 방 식과 자유 공간 광 연결(free-space optical interconnected) XOR 연산을 이용하여 암호화 및 복호화를 수행할 수 있는 광 암호화 시스템을 제안한다. 이 방식은 기존의 앞서 설명 한 XOR 연산을 이용한 암호화 방식과 달리 위상(phase) 정 보를 취급하지 않고 오직 디지털 정보 1 또는 0 을 나타내는 명암의 크기(intensity) 정보만 다룸으로써 디지털적 장점을 살리고 전자적 디지털 신호와도 잘 연동이 된다. 또한 암호 화 광학적 장치의 구성과 정렬을 쉽게 하여 광학적 시스템 구현에도 간단하다는 장점을 가진다. 본 논문은 제안된 XOR 연산의 자유 공간 병렬 처리 기법을 블록 암호화 기법의 대 표적인 $\mathrm{CBC}($ Cipher Block Chaining) 암호화 기법에 적용하 여 광 병렬 처리에 적합한 광학적인 $\mathrm{XOR}$ 연산을 이용한 변 형된 $\mathrm{CBC}$ 암호화 및 복호화 시스템을 제안하고 이의 성능 을 전산 실험을 통하여 보여준다. 또한, 제안된 암호화 시스 템을 간단한 광학적 모듈 구조로 구현하여 공학적으로 실현 가능한 새로운 광 보안 장치를 제시한다. 서론에 이어서 2장 에서는 기존의 $\mathrm{CBC}$ 암호화 알고리즘에 대해 알아본 후, $\mathrm{XOR}$ 연산의 자유 공간 병렬 처리를 이용한 변형된 $\mathrm{CBC}$ 암 호화 알고리즘을 제안하고 복호화 및 암호화 과정을 기술한 다. 또한, 제안된 방식의 광학적 장치의 구성과 동작에 관해 논한다. 3장에서는 제안한 광학적 암호화 장치의 성능을 입 증하기 위한 전산 실험의 결과를 보여주고, 4장에서 간략한 결론을 정리한다.

\section{II. $\mathrm{CBC}$ 암호화 알고리즘과 광학적 암호화 시스템 구현}

DES(Data Encryption Standard)는 대칭형 블록 암호화 방 식으로 1977년 ANSI(American National Standard Institute)와 NIST(National Institute of Standards and Technology)에 의해 처음 데이터 암호화 알고리즘의 표준으로 채택되었고, 보안 키 암호화 시스템에 널리 사용되어 상당한 보안성을 제공하 여 왔다 ${ }^{[1]}$. 그러나 최근에 암호분석가들은 이 방식의 암호키 의 크기가 강한 보안 강도를 유지하기에는 충분치 못하다고 반론을 제기하고 있다. 현재 사용되고 있는 디지털 암호화 방식의 블록 암호화 시스템에서는 $\mathrm{ECB}$ (Electronic Codebook Mode), CBC(Cipher Block Chaining), CFB(Cipher Feedback Block), OFB(Output Feedback Block) 등 4개의 표준 모드 알 고리즘이 있다. 이러한 블록 암호화 방식은 광학적 암호화 방식의 하나인 Refregier 등이 제안한 이중 무작위 위상 인코 딩 암호화 기법 ${ }^{[5]}$ 에 적용하여 해석되었다 ${ }^{[21]}$.

기존의 디지털 블록 암호화 기법 중에서 $\mathrm{ECB}$ 모드는 가장 간단한 구조의 암호화 알고리즘이고, $\mathrm{CBC}, \mathrm{CFB}, \mathrm{OFB}$ 모드 
는 좀 더 보안 강도가 높은 암호화 알고리즘이다. 본 논문에 서는 그 중 $\mathrm{CBC}$ 알고리즘의 개념을 고찰하고 이를 Boolean $\mathrm{XOR}$ 연산을 이용하여 광학적 구현이 가능한 변형된 $\mathrm{CBC}$ 알고리즘 구조를 제안하고 설명한다.

\section{1. $\mathrm{CBC}$ (Cipher Block Chaining) 암호화 알고리즘}

$\mathrm{CBC}$ 암호화 알고리즘은 첫 번째 평문을 초기에 어떤 임의 의 값과 XOR 연산을 한 뒤에 이를 암호화하여 첫 번째 암호 문을 만든다. 그 다음 두 번째 평문에 이전 암호화된 암호문 과 XOR 연산을 하고 이를 다시 암호화하여 계속해서 암호 문을 발생시키는 대칭형(symmetric) 블록 암호화 알고리즘이 다. 이 방식은 이전 암호화된 평문과 다시 또 암호화함으로 써 $\mathrm{ECB}$ 블록 암호 형식보다 훨씬 더 해독하기 어렵다는 장 점을 가진다. 블록 암호화 방식 중에서도 $\mathrm{CBC}$ 방식은 암호 화할 암호문의 패턴이 나타나지 않는 방식을 장점으로 가지 고 있다. 또한 기존의 대칭키 암호화 방식에서의 암호화할 평문과 암호화된 암호문을 만약에 동시에 도난 당한다면 암 호화 키를 알아낼 수 있기 때문에 암호화 시스템 전체가 무 력화되는 문제점을 가지지만, $\mathrm{CBC}$ 방식은 암호화할 평문과 암호화된 암호문으로 암호화 키를 알아낼 수가 없기 때문에 암호문과 평문의 쌍을 암호해독 공격자가 가지고 있다 하더 라도 이전의 암호문이 없다면 해독이 불가능한 장점을 지닌 다. $\mathrm{CBC}$ 방식의 암호화 수식은 다음과 같다.

$$
\begin{aligned}
& C_{0}=I V, \\
& C_{i}=E_{k}\left(P_{i} \oplus C_{i-1}\right), \quad 1 \leq i \leq m
\end{aligned}
$$

여기서 $I V$ 는 임의의 초기값이며 $\oplus$ 는 bit 단위의 XOR 연산 을 의미한다. $E_{k}(\cdot)$ 는 암호화 과정에서 암호화 키 $k$ 를 통한 암 호화 방법을 나타내고 $P_{\mathrm{i}}$ 는 $i$ 번째 평문, $C_{\mathrm{i}}$ 는 해당하는 암호 문을 나타낸다. 또한 $m$ 은 암호화하고자 하는 총 평문의 갯수 이다. 한편, 복호화 수식은 다음과 같다.

$$
D_{i}=D_{k}\left(C_{i}\right) \oplus C_{i-1}=P_{i}, \quad 1 \leq i \leq m
$$

여기서 $D_{k}(\cdot)$ 는 암호화 과정에서 사용된 암호화 키 $k$ 를 통한 복호화 방법을 나타낸다. $\mathrm{CBC}$ 모드의 특징은 암호문이 어떤 블록 하나에 오류가 발생한다면 해당 평문 복호화에 오류가 발생하며 다음 연산에 의한 그 다음 평문 블록의 복원에도 영향을 미친다는 점이다. 또한, 평문을 정상적으로 복호화하 기 위해선 암호문의 순서가 정확해야 한다. 그림 1(a)는 CBC 암호화 알고리즘의 흐름도를 보여준다. $\mathrm{CBC}$ 암호화 알고리 즘에서 올바르게 평문 복호화가 이루어지려면 암호키를 포 함하여 초기값 $C_{0}$ 를 암호화 측과 복호화 측에서 서로 알고 있어야만 한다. 통상적으로 초기값 $C_{0}$ 는 상호 공통키(common key)나 서로 둘 만이 교환하여 알 수 있는 비밀키(secret key) 로 설정하여 이용할 수 있다.
일반적으로 기존의 전자적 디지털 암호화 기법에는 Boolean XOR 연산이 많이 이용된다. XOR 논리 연산은 수학적으로 modulo 2 덧셈이다. 이에 $\mathrm{CBC}$ 알고리즘을 modulo 2 덧셈인 $\mathrm{XOR}$ 논리 함수로만 표현하는 수정된 $\mathrm{CBC}$ 알고리즘으로 변 형할 수 있다. 즉, 암호화 시스템의 모든 연산 과정을 수학적 으로 오직 XOR 논리 연산만으로 구성하는 변형된 $\mathrm{CBC}$ 암 호화 알고리즘을 제안한다. 특히, XOR 연산만의 암호화 방 식은 만약 데이터 암호화에 사용되는 암호화 키가 완전하게 무작위적(random)이고 결코 재사용되지 않는다면 완전하게 보안성을 유지할 수 있다. 이러한 XOR 연산에 기반한 암호 화 기법은 1 또는 0 을 표현하는 명암의 화소(pixel)로 구성된 오직 이진 데이터나 이진 영상에만 적용할 수 있고, 그리고 개별적으로 데이터 각 화소는 독립적으로 암호화된다는 것 을 의미한다. 따라서 XOR 연산 기반의 암호화 기법을 위의 $\mathrm{CBC}$ 알고리즘에 적용하면 식 (1)과 식 (2)은 다음과 같이 변 형하여 표현할 수 있다.

$$
\begin{aligned}
& C_{0}=I V, \\
& C_{i}=\left(P_{i} \oplus C_{i-1}\right) \oplus K, \quad 1 \leq i \leq m
\end{aligned}
$$

여기서 $I V$ 는 무작위하게 발생된 임의의 초기값이며 $K$ 는 암 호화에 사용된 암호화 키를 나타낸다.

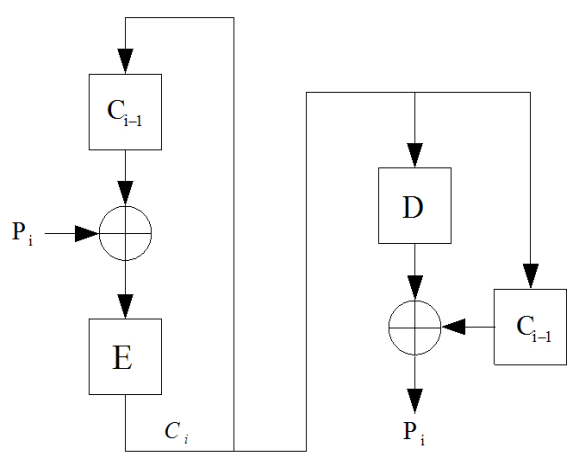

(a)

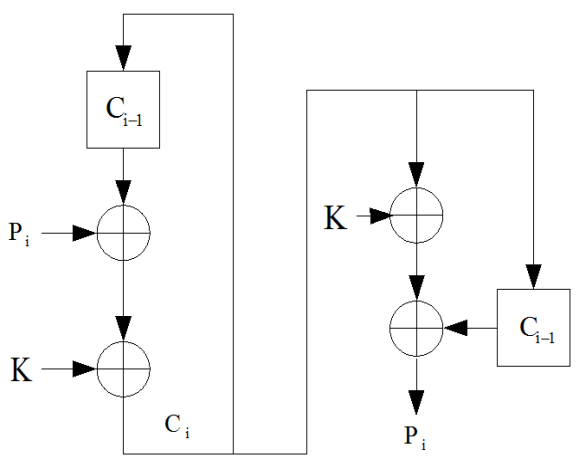

(b)

FIG. 1. Flow chart for cipher block chaining (CBC) cryptosystem algorithm. (a) the conceptual $\mathrm{CBC}$, (b) the modified CBC. 
똑같은 암호화 키를 사용하여 암호문 $C_{i}$ 로부터 원래의 평 문 $P_{i}$ 를 복원하기 위한 복호화 수식은 다음과 같다.

$$
\begin{aligned}
D_{i}=\left(C_{i} \oplus K\right) \oplus C_{i-1} & =\left[\left\{\left(P_{i} \oplus C_{i-1}\right) \oplus K\right\} \oplus K\right] \oplus C_{i-1} \\
& =P_{i}, \quad 1 \leq i \leq m
\end{aligned}
$$

마찬가지로 XOR 연산을 이중으로 이용한 변형된 $\mathrm{CBC}$ 방 식의 암호화 시스템 역시 기존 $\mathrm{CBC}$ 방식의 장점을 가지고 있다. 암호화된 암호문으로부터 원 평문을 복호화하기 위해 서는 암호화 키를 포함하여 이전 암호화된 암호문이 필요하 다. 하지만 첫 번째 평문을 복호화하기 위해선 초기값 $C_{0}$ 가 필요하다. 위 식에서 보는 것과 같이 XOR 연산을 이용한 변 형된 $\mathrm{CBC}$ 방식도 해당 블록의 암호문과 암호화 키의 쌍이 해킹되었다 하더라도 이전의 암호문이 없다면 해당 블록을 복호화할 수가 없다. 그림 1(b)는 변형된 $\mathrm{CBC}$ 암호화 알고 리즘의 흐름도를 보여준다.

\section{2. 제안된 $\mathrm{XOR}$ 연산에 기반한 $\mathrm{CBC}$ 암호화 알고리즘 의 광학적 구현}

광 논리 게이트 처리 개념은 자유 공간에서 서로 연결된 논리 게이트(free-space interconnected logic gate)로 간주되어 구성될 수 있다. 이러한 자유 공간 광 연결은 통신 시스템뿐 만 아니라 대량 디지털 광 연산에 요긴하다. 왜냐하면 이러 한 자유 공간 광 연결은 논리 함수를 광학적으로 구현하는데 효율적이며 복잡한 논리 시스템도 쉽게 광학적으로 구현할 수 있는 장점을 지니기 때문이다. 또한, 이러한 광 연결은 대 량의 정보를 2 차원적으로 표현하여 빠른 속도로 병렬 처리 할 수 있는 특성을 지닌다. 본 논문에서는 이러한 자유 공간 연결 광 논리 게이트 방법을 이용하여 광학적 XOR 연산을 구현한다. 이 방법의 또 다른 장점은 아마도 입출력 데이터 의 패턴 정합의 어려움을 해결할 수 있는 좋은 방법이기도 하다. 즉, 입출력 데이터 상의 화소 encoding-decoding 과정 이 필요 없고 출력 데이터는 입력 데이터와 같은 패턴과 크 기를 가진다. 일반적으로 논리 게이트를 광학적으로 구성하 는데 있어서는 이진 입력 변수는 2의 보수(two's complement) 를 사용하여 공간적으로 인코딩된다.

그림 2는 이중 인코딩(dual encoding)과 자유 공간 연결 광 논리 게이트 방법을 이용한 XOR 논리 연산을 수행하는 광 학적 개념도를 보여준다. 이중 인코딩 방법은 한 개의 이진 입력 정보에 대해 진수와 보수(complement)로 구성된 두 개 의 데이타 쌍으로 인코딩하는 방식이다. 즉, 이중 인코딩 방 법을 이용한 광학적 XOR 연산은 이진 정보를 진수와 보수 로 동시에 표현한 뒤 이들을 거울(M)과 beam splitter(BS)를 이용하여 XOR 연산을 구현한 방법이다. 논리적으로 XOR 연산은 주어진 두 개의 입력 변수에 대해서 이들의 진수, 보 수 표현과 AND 연산과 OR 연산으로 이루어진다. 이 과정을 자유 공간 연결 광 논리 게이트 방법을 통하여 구현을 해보 면 네 개의 공간 광 변조기(SLM: Spatial Light Modulator)에
두 입력 데이터의 진수 데이터와 보수 데이터를 표현하고, 직렬로 구성된 두 개의 SLM 쌍에 서로 다른 입력의 진수와 보수가 표현되어 빛이 통과하게 되면 AND 연산이 되고 거 울과 $\mathrm{BS}$ 를 통하여 $\mathrm{OR}$ 연산을 하도록 하여 XOR 연산을 수 행하는 기법이다. 이 간단한 과정을 통하여 처리된 XOR 연 산에 대한 논리식은 다음과 같다.

$$
X(x, y) \bullet \bar{Y}(x, y)+\bar{X}(x, y) \bullet Y(x, y)=X(x, y) \oplus Y(x, y)
$$

여기서 - 은 AND 연산, +는 OR 연산, $\oplus$ 는 XOR 연산을 의미한다.

일반적으로 대칭형 암호화 시스템의 암호 강도는 암호화 키 길이에 의존한다. 암호화 키 길이가 길수록 암호문의 해 독 공격은 더 어려워지고 암호 강도는 더 세어진다. 이러한 이유로 암호화 키 길이는 암호화 알고리즘을 규정하는데 있 어서 가장 첫 번째의 설계 요구조건이 된다. 즉, 만약 암호화 시스템을 해독하는 방법으로써 모든 가능한 암호화 키를 시 도해 보는 단순한 무제한 공격 방법밖에 없다고 가정하면, 암호화 키의 길이가 길수록 올바른 암호화 키를 찾는데 필요 한 더 많은 공격 시간이 요구되게 된다. 일반적으로 암호화 키가 N bits의 길이를 가지면 올바른 암호화 키를 찾기 위해 서는 $2^{\mathrm{N}}$ 번의 시도가 필요하다. 하지만 암호 강도를 높이기 위해 암호화 키의 길이를 증가시키면 암호화 및 복호화 처리 시간 그리고 암호문 전송시간이 오래 걸리게 되는 단점이 있 다. 또한 최근에는 전송 기술이 발전함에 따라 전송 속도를 따라가기 위해서 더 빠른 암호화 시간이 요구되고 있는 실정 이다. 이러한 요구 조건을 만족하기 위해서 광학적 암호화 방식은 그 대안이 될 수 있다. 광학 시스템은 본질적으로 2 차원 데이터 처리와 빠른 병렬 정보 처리 특성을 지니고 있 다. 따라서 암호화 알고리즘을 광학적 장치로 구현하고 암호 화 키의 길이를 2 차원 배열로 확대하여 증가시키면 암호 강 도뿐만 아니라 데이터 처리 속도도 동시에 향상시킬 수 있 다. 만약 2 차원 암호키의 크기가 $\mathrm{N} \times \mathrm{M}$ pixels로 구성된다면 이 암호화 시스템을 풀기 위한 올바른 암호화 키를 찾는 시 도는 $2^{\mathrm{N} \times \mathrm{M}}$ 으로 엄청나게 증가될 것이다. 그렇다고 광학적 암

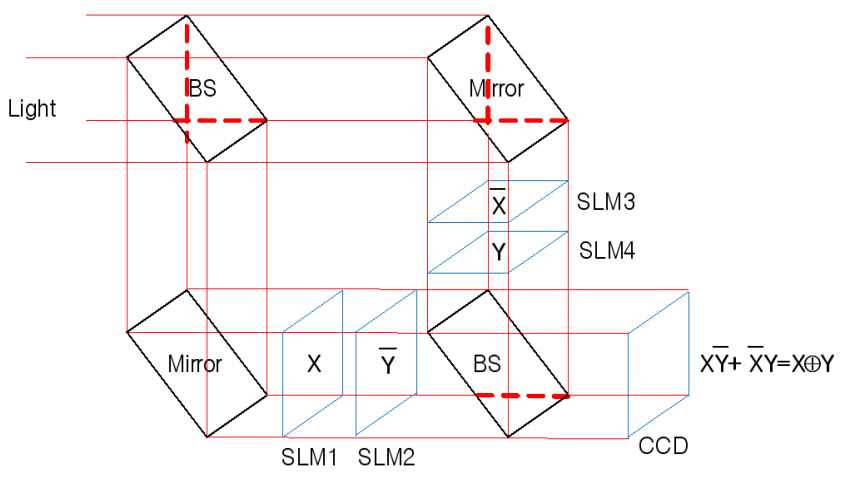

FIG. 2. XOR logic operation using dual encoding and the free-space interconnected optical logic gate method. 
호화 시스템에서는 데이터의 2차원 확장이 암호화 속도를 줄이지는 않는다. 이러한 특성을 바탕으로 본 논문에서는 페 이지 블록 형태의 2 차원 암호화 키와 평문을 구성하고 이 블 록 형태와 같은 2차원 암호문 출력 구조를 갖는 XOR 연산 기반의 자유 공간 병렬 처리를 이용한 광학적 $\mathrm{CBC}$ 블록 암 호화 기법을 제안한다.

본 논문에서 제안한 $\mathrm{CBC}$ 암호화 기법을 광학적으로 구현 하기 위해서는 몇 가지 요구 조건이 필요하다. 그 중 첫 번 째는 암호화된 암호문이 디지털 방식으로 기록되어 전송되 어야 한다. 그래야만 암호문이 피드백 시스템에서 동일한 구 조와 양식으로 사용될 수 있다. 두 번째는 암호화 및 복호화 과정에서 이진 데이터를 공간 표시 장치에 전자적으로 빨리 교체가 가능하도록 입력시킬 수 있어야 한다. 이러한 요구 조건들은 전자적 제어가 가능한 $\mathrm{CCD}$ 와 $\mathrm{SLM}$ 을 각각 기록 장치와 입력 장치로 사용함으로써 해결된다. 그림 3 은 본 논 문에서 제안한 이중 인코딩 방법과 자유 공간 광 연결 XOR 논리 연산에 기반한 변형된 $\mathrm{CBC}$ 알고리즘의 암호화 및 복 호화의 광학적 구현을 위한 개념적 구성도를 보여준다. 그림 3(a)에서 광학적 구성도는 기본적으로 세 개의 MachZehnder 간섭계 형태의 공간 광 연결을 포함한다. 우선 입사 광을 두 경로로 나누는 $\mathrm{BS} 1, \mathrm{BS} 2, \mathrm{BS} 3$ 와 거울 $\mathrm{M} 1$ 에 의해 광원으로부터 온 빛을 네 개의 평면광 경로로 나눈다. 나뉘 어진 광 경로 중 $\mathrm{BS} 1$ 에 의해 오른쪽 거울 $\mathrm{M} 2$ 로 진행하는 광 경로 사이에는 두 개의 SLM이 직렬적으로 위치하고 있 다. 마찬가지로 $\mathrm{BS} 2$ 에 의해 오른쪽 거울 $\mathrm{M} 3$ 로 진행하는 광

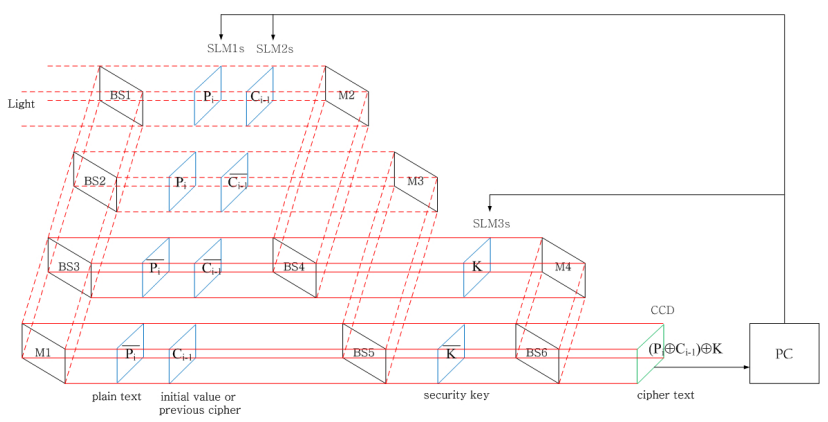

(a)

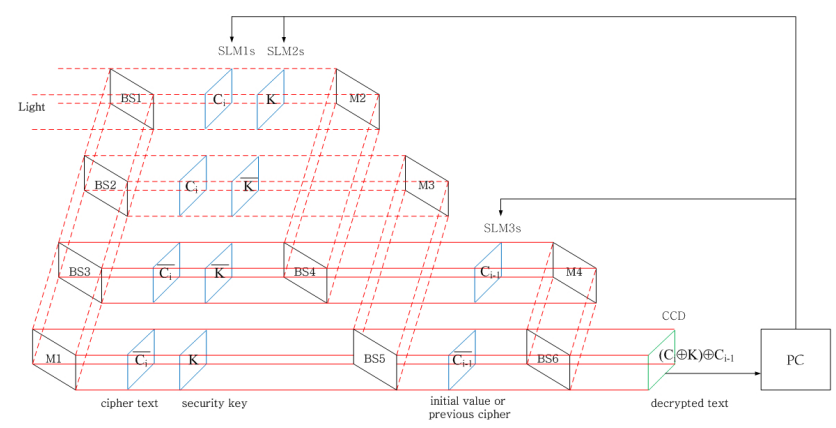

(b)

FIG. 3. Schematic optical architecture for the modified CBC algorithm based on the free-space interconnected XOR logic operations: (a) encryption, (b) decryption.
경로 사이와 $\mathrm{BS} 3$ 에 의해 오른쪽 $\mathrm{BS} 4$ 로 진행하는 광 경로 사 이, 그리고 거울 $\mathrm{M} 1$ 에 의해 BS5로 진행하는 광 경로 사이에 도 각각 두 개의 $\mathrm{SLM}$ 이 직렬적으로 위치하고 있다. 여기서 거울 $\mathrm{M} 2$ 는 $\mathrm{BS} 1$ 에 의해 나뉘어져 진행된 빛을 $\mathrm{BS} 4$ 로 반사 시키고 거울 $\mathrm{M} 3$ 는 $\mathrm{BS} 2$ 에 의해 나뉘어져 진행된 빛을 $\mathrm{BS} 5$ 로 반사시킨다. 또한 $\mathrm{BS} 4$ 를 통과한 빛은 거울 $\mathrm{M} 4$ 에 의해 반 사하기 전 한 개의 $\mathrm{SLM}$ 을 지나게 되고, BS5를 통과한 빛은 $\mathrm{BS} 6$ 을 통과하기 전 한 개의 SLM을 지나게 된다. 마지막으 로 $\mathrm{BS} 6$ 는 이 두 빛을 합하여 $\mathrm{CCD}$ 로 보내 출력을 기록한다. 제안한 광학적 구성도에서 이중 인코딩을 이용한 XOR 연산 과 변형된 $\mathrm{CBC}$ 블록 암호화 알고리즘을 수행하기 위해서 각 SLM들은 다음과 같이 데이터가 표시된다. 우선 그림에서 SLM1's로 표현된 네 개의 SLM에는 순서적으로 암호화하고 자 하는 평문의 진수 데이터 $P_{i}$ 와 보수 데이터 $\bar{P}_{i}$ 가 그림에 서와 같이 입력 데이터로써 표시되고, 이와 직렬적으로 정렬 배치된 SLM2's로 표현된 네 개의 SLM에는 이전에 암호화 되어 $\mathrm{CCD}$ 에 의해 기록된 이전 단계 암호문의 진수 데이터 $C_{i-1}$ 와 보수 데이터 $\overline{C_{i-1}}$ 가 교대로 표시된다. 하지만 첫 번째 암호화 과정에서는 SLM2's에는 임의의 초기값의 진수 $C_{0}$ 와 보수 $\overline{C_{0}}$ 가 표시된다. 이렇게 표시된 이진 값들은 두 개의 $\mathrm{SLM}$ 을 직렬로 통과하면서 AND 연산을 수행하게 된다. 그 다음, $\mathrm{M} 1$ 에 의해 반사된 첫 번째 광 경로에서 $\mathrm{AND}$ 연산의 결과 얻어진 $P_{i} \bullet C_{i-1}$ 과 $\mathrm{BS} 3$ 로부터 입사한 세 번째 광 경로 에서 얻어진 $\mathrm{AND}$ 연산의 결과 $\overline{P_{i}} \bullet \overline{C_{i-1}}$ 는 $\mathrm{BS} 4$ 에 의해 더해 져 $\mathrm{OR}$ 연산되고 그 결과로 $P_{i} \bullet C_{i-1}+\overline{P_{i}} \bullet \overline{C_{i-1}}=\overline{P_{i} \oplus C_{i-1}}$ 로 표현되는 XNOR 연산 결과가 된다. 비슷하게, $\mathrm{BS} 2$ 로부터 입 사한 두 번째 광 경로에서 얻어진 $\mathrm{AND}$ 연산의 결과 $P_{i} \bullet \overline{C_{i-1}}$ 과 $\mathrm{M} 2$ 에 의해 반사된 네 번째 광 경로에서 얻어진 $\mathrm{AND}$ 연산의 결과 얻어진 $\bar{P}_{i} \bullet C_{i-1}$ 는 $\mathrm{BS} 5$ 에 의해 $\mathrm{OR}$ 연산 되고 그 결과로 $P_{i} \bullet \overline{C_{i-1}}+P_{i} \bullet \overline{C_{i-1}}=P_{i} \oplus C_{i-1}$ 와 같은 $\mathrm{XOR}$ 연산이 된다. 마지막으로, 이렇게 연산된 $\mathrm{XNOR}$ 결과와 $\mathrm{XOR}$ 결과는 암호화에 필요한 암호화 키의 진수 데이터 $K$ 와 보수 데이터 $\bar{K}$ 가 표시된 SLM3's를 각각 통과하여 AND 연산을 수행하고, 그 결과 $\overline{P_{i} \oplus C_{i-1}} \bullet K$ 와 $P_{i} \oplus C_{i-1} \bullet \bar{K}$ 를 얻 는다. 이 두 광 정보는 마지막 $\mathrm{BS} 6$ 에 의해 $\mathrm{OR}$ 연산되고 최 종적으로 $\mathrm{CCD}$ 에 기록되는 암호문은 $\overline{P_{i} \oplus C_{i-1}} \bullet K+P_{i} \oplus C_{i-1}$ - $\bar{K}=P_{i} \oplus C_{i-1} \oplus K$ 과 같이 $\mathrm{CBC}$ 블록 암호화된 암호문 $C_{i}$ 를 나타낸다. 계속해서 다음 페이지의 블록 데이터의 암호화 를 수행하기 위해선 $\mathrm{CCD}$ 에 기록된 암호문을 $\mathrm{PC}$ 에 보내고, $\mathrm{PC}$ 는 이 암호문을 SLM2's에 피드백 시켜 표시함으로써 그 다음 번째 평문과 암호화를 계속해서 수행한다.

흥미롭게도 본 논문에서 제안한 암호화 구성도는 SLM에 표시되는 정보의 순서를 바뀌줌으로써 똑같은 광학 구성 장 치를 사용해 쉽게 복호화 과정도 수행할 수 있다. 그림 3(b) 는 이러한 복호화 광학 구성도를 보여준다. 제안한 광학적 구성도에서 이중 인코딩을 이용한 $\mathrm{XOR}$ 연산과 변형된 $\mathrm{CBC}$ 
블록 복호화 알고리즘을 수행하기 위해서 각 SLM들은 다음 과 같이 데이터가 표시된다. 우선 그림에서 SLM1's로 표현 된 네 개의 $\mathrm{SLM}$ 에는 전송되어 온 암호문의 진수 데이터 $C_{i}$ 와 보수 데이터 $\overline{C_{i}}$ 가 그림에서와 같이 암호문 데이터로써 표시되고, 이와 직렬로 배치된 SLM2's로 표현된 네 개의 $\mathrm{SLM}$ 에는 암호화에 사용된 똑같은 암호화 키의 진수 데이터 $K$ 와 보수 데이터 $\bar{K}$ 가 교대로 표시된다. 이렇게 표시된 이진 값들은 두 개의 SLM을 직렬로 통과하면서 AND 연산을 수 행하게 된다. 그 다음, $\mathrm{M} 1$ 에 의해 반사된 첫 번째 광 경로에 서 $\mathrm{AND}$ 연산의 결과 얻어진 $C_{i} \bullet K$ 와 $\mathrm{BS} 3$ 로부터 입사한 세 번째 광 경로에서 얻어진 $\mathrm{AND}$ 연산의 결과 $\overline{C_{i}} \bullet \bar{K}$ 는 $\mathrm{BS} 4$ 에 의해 더해져 $\mathrm{OR}$ 연산되고 그 결과로 $C_{i} \bullet K+\overline{C_{i}}$ - $\bar{K}=\overline{C_{i} \oplus K}$ 로 표현되는 $\mathrm{XNOR}$ 연산 결과가 된다. 마찬가 지로, $\mathrm{BS} 2$ 로부터 입사한 두 번째 광 경로에서 얻어진 $\mathrm{AND}$ 연산의 결과 $C_{i} \bullet \bar{K}$ 과 $\mathrm{M} 2$ 에 의해 반사된 네 번째 광 경로에 서 얻어진 $\mathrm{AND}$ 연산의 결과 얻어진 $C_{i} \bullet \bar{K}$ 는 $\mathrm{BS} 5$ 에 의해 $\mathrm{OR}$ 연산되고 그 결과로 $C_{i} \bullet \bar{K}+\overline{C_{i}} \bullet K=C_{i} \oplus K$ 와 같은 $\mathrm{XOR}$ 연산이 된다. 마지막으로, 이렇게 연산된 XNOR 결과 와 XOR 결과는 복호화에 필요한 첫 번째 암호화 과정에서 사용된 초기값의 진수 $C_{0}$ 와 보수 $\overline{C_{0}}$ 가 표시된 SLM3's를 각각 통과하여 $\mathrm{AND}$ 연산을 수행하고, 그 결과 $\overline{C_{i} \oplus K} \bullet C_{0}$ 와 $C_{i} \oplus K \bullet \overline{C_{0}}$ 를 얻는다. 이 두 광 정보는 마지막 $\mathrm{BS} 6$ 에 의해 $\mathrm{OR}$ 연산되고 최종적으로 $\mathrm{CCD}$ 에 기록되는 데이타는 $\overline{C_{i} \oplus K} \bullet C_{0}+C_{i} \oplus K \bullet \overline{C_{0}}=C_{i} \oplus K \oplus C_{0}$ 와 같이 $\mathrm{CBC}$ 블록 복호화 데이터로 원래의 평문 $P_{i}$ 가 복원된다. 계속해서 다음 페이지의 블록 데이터의 복호화를 수행하기 위해선 계속해 서 전송되어 온 암호문을 PC가 SLM1's에 계속 순차적으로 표시함으로써 그 다음 번째 평문이 계속해서 복호화된다.

본 논문에서 제안된 변형된 $\mathrm{CBC}$ 블록 암호화 기법에 대한 그림 3의 광학적 구성도는 공학적으로 실제 구현 가능한 광 모듈의 형태로 제작할 수 있다. 이는 식 (3)과 식 (4)을 간단 한 논리 연산을 통하여 다음과 같은 등가의 논리식을 얻음으 로써 이를 광학적으로 쉽게 제작할 수 있게 한다.

$$
\begin{aligned}
C_{i}= & \left(P_{i} \oplus C_{i-1}\right) \oplus K \\
= & P_{i} \bullet C_{i-1} \bullet K+\overline{P_{i}} \bullet \overline{C_{i-1}} \bullet K \\
& +P_{i} \bullet \overline{C_{i-1}} \bullet \bar{K}=\overline{P_{i}} \bullet C_{i-1} \bullet \bar{K} \\
D_{i}= & \left(C_{i} \oplus K\right) \oplus C_{i-1} \\
= & C_{i} \bullet K \bullet C_{i-1}+\overline{P_{i}} \bullet K \bullet \overline{C_{i-1}} \\
& +P_{i} \bullet \bar{K} \bullet \overline{C_{i-1}}+\overline{P_{i}} \bullet \bar{K} \bullet C_{i-1}=P_{i}
\end{aligned}
$$

위의 식 (6)과 식 (7)에서 알 수 있듯이 세 개의 입력 변수 의 XOR 연산은 각 변수의 진수와 보수의 조합으로 이루어
진 세 개의 $\mathrm{AND}$ 연산과 세 개의 $\mathrm{OR}$ 연산의 조합 논리식으 로 표현될 수 있다. 그림 4(a)는 이러한 조합 논리식을 연산 하기 위해 제안한 간략화된 광학적 모듈 구조를 보여준다. 그림에서 보여지는 세 개의 SLM은 암호화 과정과 복호화 과정에서 평문과 암호문과 암호화 키의 식 (6)과 식 (7)을 만 족하는 진수와 보수를 이중 인코딩 방식으로 같은 SLM에 표시한다. 이는 그림 3 의 개념적 광학 구성도보다 SLM의 숫 자를 줄일 수 있다. 앞에서의 기술과 마찬가지로 세 개의 $\mathrm{SLM}$ 의 직렬 배치는 각 $\mathrm{SLM}$ 에 표현되는 입력 변수의 $\mathrm{AND}$ 연산을 수행하고 세 개의 $\mathrm{BS}$ 는 세 번의 $\mathrm{OR}$ 연산을 수행하 게 된다. 여기서 pixel matching aperture는 각 입력 변수의 진수와 보수를 표시하는 SLM에 표현되는 화소들의 정합과 회절 전파의 차단을 위해 도입되었다. 또한 imaging lens는 $\mathrm{SLM}$ 의 화소 크기와 $\mathrm{CCD}$ 의 화소 크기를 정합시키는데 사용 된다. 이 광 모듈도 역시 SLM에 표시하는 입력 변수의 변환 을 통해 복호화 과정을 수행할 수 있다. 그림 4(b)와 (c)는 암 호화 과정과 복호화 과정에서 각 SLM들에 표시되는 입력 변수들과 이때 $\mathrm{CCD}$ 에 기록되는 암호화 데이터와 복호화 데 이터를 나타낸다.

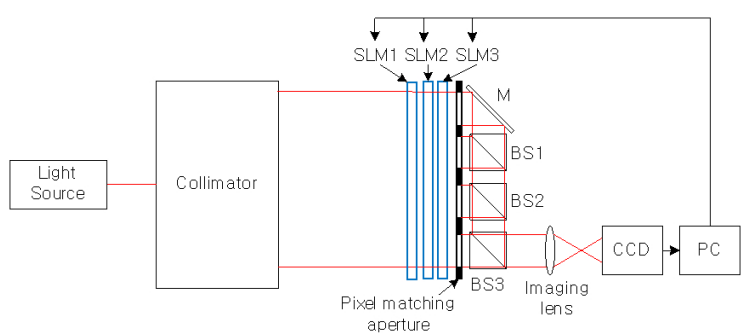

(a)

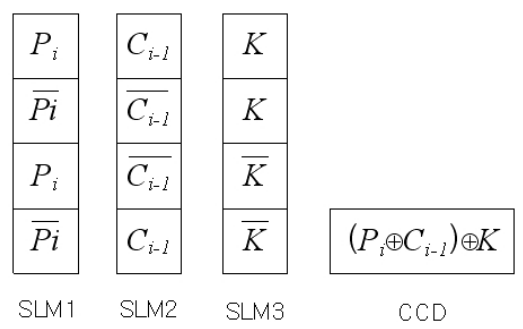

(b)

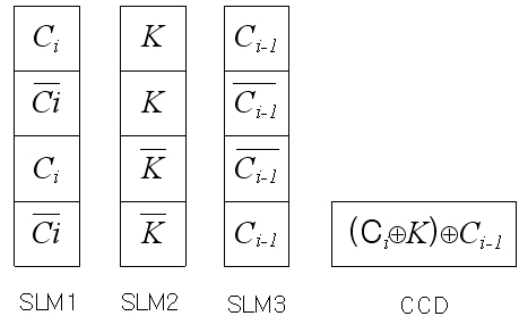

(c)

FIG. 4. Optical implementation for the modified CBC cryptosystem: (a) the proposed optical module, (b) representation of input SLM's data and output CCD's data for encryption, (c) representation of input SLM's data and output CCD's data for decryption. 


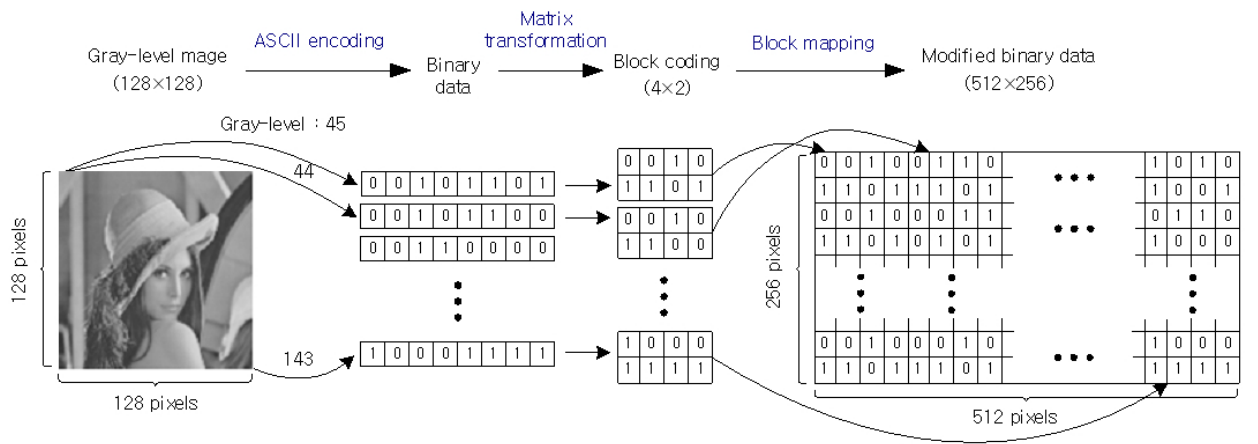

FIG. 5. Procedure of ASCII encoding and block mapping for converting a 256 gray-level optical image into binary data.

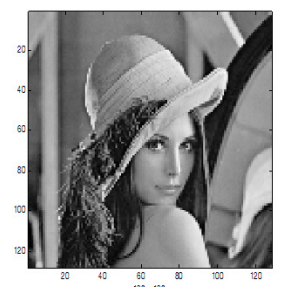

(a)

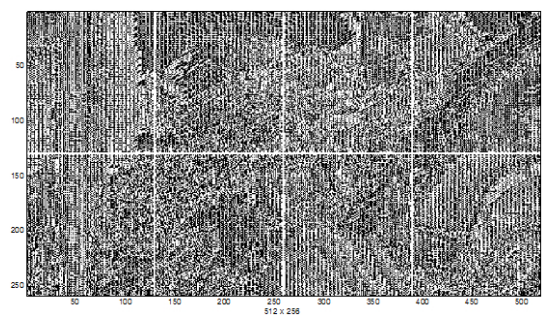

(d)

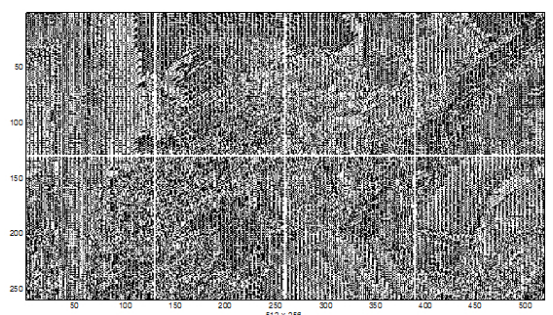

(f)

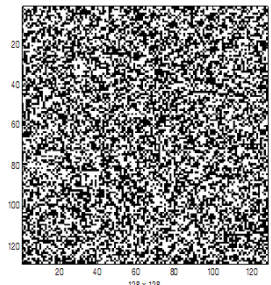

(b)

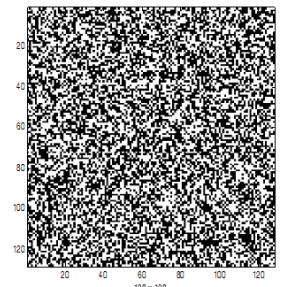

(c)

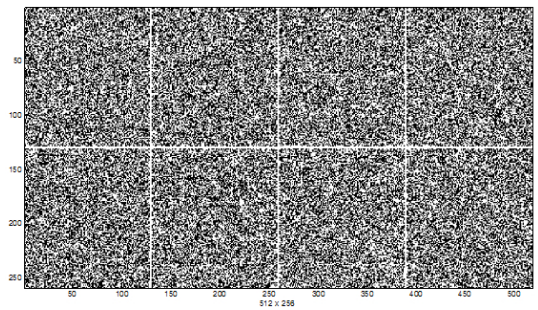

(e)

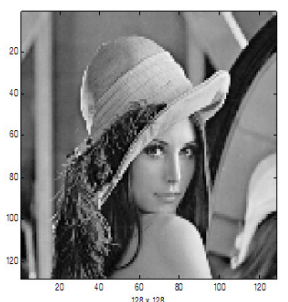

(g)

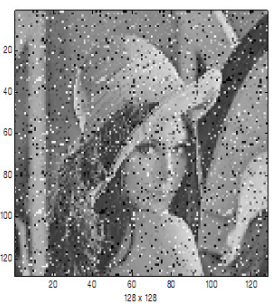

(h)

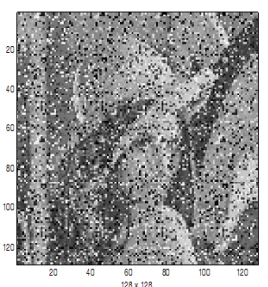

(i)

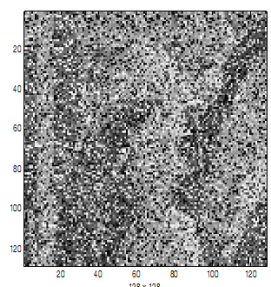

(j)

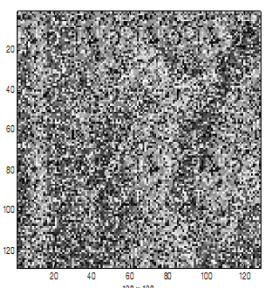

(k)

FIG. 6. Computer simulations: (a) a 256 gray-level Lena image to be encrypted(128×128 pixels), (b) a randomly generated binary code as a security key(K, $128 \times 128$ pixels), (c) a randomly generated initial value for $\mathrm{CBC}$ encryption algorithm( $C_{0}, 128 \times 128$ pixels), (d) 8 blocks of the converted binary data by ASCII encoding method(plain text to be encrypted $P_{1} \sim P_{8}, 512 \times 256$ pixels), (e) 8 blocks of the encrypted data by the security key and the previous cipher text(cipher text $C_{1} \sim C_{8}, 512 \times 256$ pixels), (f) 8 blocks of the decrypted data by the security key and the previous cipher text(decrypted text $D_{1} \sim D_{8}, 512 \times 256$ pixels), (g) the correctly decrypted Lena image by the correct security key, (h) the decrypted image by the incorrect security key with $10 \%$ error bits, (i) the decrypted image by the incorrect security key with $30 \%$ error bits, (j) the decrypted image by the incorrect security key with $50 \%$ error bits, (k) the decrypted image by the incorrect security key with $70 \%$ error bits. 


\section{III. 컴퓨터 시뮬레이션}

본 논문에서 제안한 XOR 연산의 자유 공간 병렬 처리를 이용한 광학적 $\mathrm{CBC}$ 블록 암호화 기법의 성능을 검증하기 위해 전산 실험을 하였다. 본 논문에서 사용할 수 있는 암호 화할 입력 데이터는 Boolean XOR 연산을 하기 위해서 반드 시 이진 데이터나 영상이어야만 한다. 그러므로 만약 graylevel 영상을 본 논문에서 제안한 방법으로 암호화하려면 이 진 데이터로 변환되어야만 한다. 이러한 256 gray-level의 영 상을 8-bits 이진 데이터의 배열로 변환시키는 아날로그-디지 털 ASCII 인코딩 기법은 이전 연구 논문에 소개되었다 ${ }^{[12]}$. 본 논문에서는, 하나의 gray-level 값에 해당하는 화소는 블 록 코딩에 의해 8-bits 이진 데이터로 변환되어 $4 \times 2$ 화소를 갖는 하나의 블록에 배열된다. 그러면 $128 \times 128$ 화소를 갖는 영상 데이터는 블록 매핑(block mapping)에 의해 $512 \times 256$ 화소 크기를 가지는 블록 데이터로 확장된다. 그림 5 는 이러 한 ASCII 인코딩과 블록 매핑 방법에 의한 일련의 과정을 보여준다.

본 논문에서 시뮬레이션에 사용된 암호화 목표 영상은 대 표적인 표준 영상인 256 gray-level의 Lena 영상을 사용하였 고, 이를 그림 6(a)에 나타내었다. 그림 6(b)는 암호화와 복호 화에 사용되는 $128 \times 128$ 화소 크기를 갖는 하나의 2 차원 블 록으로 구성된 암호화 키를 보여준다. 여기서 암호화 키는 편의상 무작위 값을 갖게 발생시켰고, 수치적으로 하얀 화소 는 1 , 검은 화소는 0 을 의미한다. 암호화 키의 크기가 $128 \times 128$ 화소라는 것은 암호화 키의 길이가 $16,384 \mathrm{bits}$ 라는 의미이며, 암호 강도는 올바른 암호화 키를 찾기 위해 $2^{16,384}$ 번의 시도가 필요하다는 것을 의미한다. 그림 $6(\mathrm{c})$ 는 $\mathrm{CBC}$ 암호화 기법에 필요한 초기값 $C_{0}$ 를 나타내며 역시 편의상 무 작위 값을 갖도록 발생시켰다. 그림 6(d)는 그림 6(a)의 Lena 영상을 $\mathrm{ASCII}$ 인코딩 방법에 의해 이진 데이터로 변환된 암 호화할 8 블록의 평문을 나타낸다. 한 블록의 크기는 $128 \times 128$ 화소 크기를 가지며 왼쪽 위부터 시계방향으로 평문 $P_{1}, P_{2}$, $\cdots, P_{8}$ 을 나타낸다. 그림 6(e)는 암호화 키와 초기값 $C_{0}$ 와 이 전 암호문을 사용하여 변형된 $\mathrm{CBC}$ 방식으로 블록 암호화된 암호문을 보여준다. 본 논문에서 제안한 자유 공간 광 연결 $\mathrm{XOR}$ 논리 게이트의 특성으로 출력 암호문의 한 블록의 크 기는 입력 평문과 같은 $128 \times 128$ 화소의 크기를 가지며 왼쪽 위부터 시계방향으로 암호문 $C_{1}, C_{2}, \cdots, C_{8}$ 을 나타낸다. 이 러한 암호문은 디지털 데이터 형태로 현재 사용되고 있는 디 지털 통신망을 통하여 추가적인 변환 없이 기존의 디지털 통 신 방식으로 전송할 수 있다. 그림 6(f)는 전송되어 온 암호 문과 암호화에 사용된 암호화 키를 이용하여 복호화된 8 블 록의 복호화 데이터를 보여준다. 이때 암호화 초기값 $C_{0}$ 가 복호화 과정에서 사용된다. 마찬가지로 한 블록의 크기는 입 력 평문과 같은 $128 \times 128$ 화소의 크기를 가지며 왼쪽 위부터 시계방향으로 복호화 데이터 $D_{1}, D_{2}, \cdots, D_{8}$ 을 나타낸다. 그 림 6(g)는 그림 6(f)에 보여진 암호화에 사용된 올바른 암호 화 키로 복호화된 데이터를 ASCII 디코딩 과정을 통해 올바
르게 복원된 원래의 Lena 영상을 보여준다. 한편 그림 6(h) (k)는 복호화 과정에서 암호화에 사용된 암호화 키가 무작위적으로 각각 $10 \%, 30 \%, 50 \%, 70 \%$ 의 그릇된 키 정보 를 가지고 있을 때 복호화된 데이터를 $\mathrm{ASCII}$ 디코딩 과정을 통해 복원된 영상을 보여준다. 그림에서 알 수 있듯이 오차 를 포함한 암호화 키의 정도에 따라 원래의 Lena 영상이 잘 복원되지 않음을 보여준다.

\section{IV. 결 론}

본 논문에서는 기존의 블록 암호화의 대표적인 방법 중에 서 $\mathrm{CBC}$ 방법을 $\mathrm{XOR}$ 연산을 이용하여 변형된 새로운 $\mathrm{CBC}$ 블록 암호화 기법을 광학적으로 구현한 암호화 및 복호화 시 스템을 제안하였으며, 전산 시뮬레이션을 통해 제안된 방법 의 구현 가능성을 확인하였다. 여기서 XOR 연산의 광학 병 렬 처리를 위해서 이중 인코딩 방법과 자유 공간 연결 광 논 리 게이트 방법을 사용하였다. 제안한 방법의 광학적 구성도 는 AND 연산이나 OR 연산 같은 광 논리를 자유 공간상에 연결하기 위한 거울과 $\mathrm{BS}$ 와 암호화할 평문과 암호화 키를 2 차원 배열로 표시하는 SLM, 암호문을 기록하기 위한 $\mathrm{CCD}$ 등으로 매우 간단히 구현되고, 이 암호화 구성도는 같은 구 조를 사용하여 복호화를 수행할 수 있다. 그리고 이러한 광 학적 암호화 방식은 Fourier 평면에서 복소 함수 암호화 키 를 사용하는 광학적 암호화 방식, $\mathrm{LCD}$ 의 편광을 이용한 XOR 광 암호화 방식과 phase-encoded XOR 연산 기반의 암 호화 방법보다 광학 장치 소자들의 광학적 정렬이 횔씬 더 용이하다. 또한 제안된 XOR 연산 기반의 $\mathrm{CBC}$ 암호화 방식 의 광학적 구성도를 공학적으로 실제 구현 가능한 광 모듈의 형태로 제안되어 실질적인 광 암호화 장치를 제작할 수 있 다. 제안된 방법은 기존의 $\mathrm{CBC}$ 방식을 광학적으로 구현했기 때문에 기존의 디지털적인 $\mathrm{CBC}$ 방식의 장점과 광학적인 고 속성과 병렬 처리의 특성으로 인해 많은 정보를 빠른 속도로 암호화 및 복호화하는 것이 가능하다. 한편, 광 병렬 처리의 특성상 2 차원 평문 데이터와 암호키를 사용함으로써 블록 데이터 크기가 증가하므로 기존의 전자적 $\mathrm{CBC}$ 방식보다도 한층 암호 강도가 강력해진 암호화 시스템이라고 할 수가 있 다. 본 논문에서는 암호키의 크기를 $128 \times 128$ 화소로 하여 암 호 강도는 올바른 암호화 키를 찾기 위해 $2^{16,384}$ 번의 시도가 필요한 암호화 시스템을 보여주었다. 만약 입력 SLM과 출력 $\mathrm{CCD}$ 가 더 큰 크기의 2 차원 화소를 처리할 수 있으면 더 높 은 강도의 암호화 시스템이 될 뿐만 아니라 암호화 처리 용 량도 커지게 된다. 한편 본 논문에 제안된 광학적 암호화 방 식과 광학 시스템은 $\mathrm{CBC}$ 방식 외에 $\mathrm{ECB}$ 방식과 $\mathrm{CFB}$ 방식 에도 적용할 수 있다.

\section{References}

1. B. Schneier, Applied Cryptography, 2nd ed. (John Wiley, New York, USA, 1994). 
2. C. Li, S. Li, M. Asim, J. Nunez, G. Alvarez, and G. Chen, "On the security defects of an image encryption scheme," Ima. and Vis. Comp. 27, 1371-1381 (2009).

3. B. Javidi and J. L. Horner, "Optical pattern recognition for validation and security verification," Opt. Eng. 33, 1752-1756 (1994).

4. J. F. Heanue, M. C. Bashaw, and L. Hesselink, "Encrypted holographic data storage based on orthogonal-phase-code multiplexing," Appl. Opt. 34, 6012-6015 (1995).

5. P. Refregier and B. Javidi, "Optical image encryption based on input plane and Fourier plane random encoding," Opt. Lett. 20, 767-769 (1995).

6. B. Javidi, A. Sergent, and E. Ahouzi, "Performance of double phase encoding encryption technique using binarized encrypted images," Opt. Eng. 37, 565-569 (1998).

7. D. Weber and J. Trolinger, "Novel implementation of nonlinear joint transform correlators in optical security and validation," Opt. Eng. 38, 62-68 (1999).

8. T. Nomura and B. Javidi, "Optical encryption using a joint transform correlator architecture,” Opt. Eng. 39, 2031-2035 (1999).

9. E. Cuche, F. Bevilacqua, and C. Depeursinge, "Digital holography for quantitative phase-contrast imaging," Opt. Lett. 24, 291-293 (1999).

10. G. Unnikrishnan and K. Singh, "Double random fractional Fourier domain encoding for optical security," Opt. Eng. 39, 2853-2859 (2000).

11. X. Meng, L. Z. Cai, X. L. Yang, X. X. Shen, and G. Y. Dong, and Y. R. Wang, "Two-step phase-shifting interferometry and its application in image encryption," Opt. Lett. 31, 1414-1416 (2006).
12. S. H. Jeon, Y. G. Hwang, and S. K. Gil, "Optical encryption of gray-level image using on-axis and 2-f digital holography with two-step phase-shifting method," Opt. Rev. 15, 181-186 (2008).

13. S. H. Jeon and S. K. Gil, "Dual optical encryption for binary data and secret key using phase-shifting digital holography," J. Opt. Soc. Korea 16, 263-269 (2012).

14. G.-S. Lin, H. T. Chang, W.-N. Lie, and C.-H. Chuang, "Public-key-based optical image cryptosystem based on data embedding techniques," Opt. Eng. 42, 2331-2339 (2003).

15. T. Nomura, A. Okazaki, M. Kameda, and Y. Morimoto, "Image reconstruction from compressed encrypted digital hologram," Opt. Eng. 44, 2313-2320 (2005).

16. J.-W. Han, C.-S. Park, D.-H. Ryu, and E.-S. Kim, "Optical image encryption based on XOR operations," Opt. Eng. 38, 47-54 (1999).

17. G. Unnikrishnan, M. Pohit, and K. Singh, "A polarization encoded encryption system using ferroelectric spatial light modulator," Opt. Commun. 185, 25-31 (2000).

18. J. Y. Kim, S. J. Park, C. S. Kim, J.-G. Bae, and S.-J. Kim, "Optical image encryption using interferometry-based phase mask," Electron. Lett. 36, 874-875 (2000).

19. C.-M. Shin and S.-J. Kim, "Image encryption using modified exclusive-OR rules and phase-wrapping technique," Opt. Commun. 254, 67-75 (2005).

20. S. Bahrami and M. Naderi, "Image encryption using a lightweight stream encryption algorithm," Adv. in Mult. 2012, 1-8 (2012).

21. T. Naughton, B. Hennelly, and T. Dowling, "Introducing secure modes of operation for optical encryption," J. Opt. Soc. Am. A 26, 2608-2617 (2008). 